\title{
Abrupt-onset, profound erectile dysfunction in a healthy young man after initiating over-the-counter omeprazole: a case report
}

Theodore W. Perry

\begin{abstract}
Background: Proton pump inhibitors are frequently used (and often overused) medications with adverse effects including vitamin B12 deficiency, Clostridium difficile colitis, and increased risk of chronic kidney disease. Erectile dysfunction is largely unrecognized as an adverse effect of proton pump inhibitors despite increasing evidence that proton pump inhibitors may contribute to impaired nitric oxide generation and endothelial dysfunction.

Case presentation: A 38-year-old Caucasian man with mild hypertension and no other significant medical history developed profound erectile dysfunction within 2 days of initiating over-the-counter omeprazole therapy, with erectile function rapidly normalizing following discontinuation of the drug. At the time of the episode, the patient was on a stable dose of lisinopril and was taking no other medications or supplements. In the 2 years following the episode, the patient has had no further erectile difficulties.

Conclusion: Further study of erectile dysfunction as an adverse effect of proton pump inhibitors is needed. In the meantime, proton pump inhibitors should be considered as a potential cause of erectile dysfunction in healthy young patients and as a cause or contributor to erectile dysfunction in older patients in whom erectile dysfunction is often attributed to age or comorbidities.
\end{abstract}

Keywords: Proton pump inhibitor, Omeprazole, Erectile dysfunction, Endothelial dysfunction, Case report

\section{Introduction/background}

Proton pump inhibitors (PPIs) are indicated for the management of peptic ulcer disease and gastroesophageal reflux disease. The utility of PPIs in these settings owes to their inhibition of the hydrogen-potassium ATPase in gastric parietal cells, which decreases the release of hydrogen ions into the gastric lumen and lowers gastric acidity [1]. A number of uncommon but well-recognized adverse effects of PPIs (for example, vitamin B12 malabsorption, Clostridium difficile colitis, reduced bone density) are likely consequences of this primary mechanism of action [2-4]. However, the pathophysiology of other

*Correspondence: twperry95@gmail.com

North Texas VA Medical Center, Dallas, TX, USA associated adverse effects (for example, increased risk of chronic kidney disease and cardiovascular events) is less clear, suggesting that PPIs likely interact with other physiologic processes $[5,6]$. In light of the wide use (and often overuse) of PPIs, a more complete characterization of potential adverse effects is needed.

Erectile dysfunction (ED) most commonly affects older men (age > 40 years) and is strongly associated with risk factors including coronary artery disease, diabetes mellitus, hypertension, obesity, and smoking [7-9]. In addition, certain medications are considered frequent precipitants of ED. These medications include selective serotonin reuptake inhibitors, spironolactone, thiazide diuretics, and some H2-receptor blockers (for example, cimetidine) $[10,11]$. PPIs are largely unrecognized as a potential cause or contributor to ED, despite increasing original author(s) and the source, provide a link to the Creative Commons licence, and indicate if changes were made. The images or other third party material in this article are included in the article's Creative Commons licence, unless indicated otherwise in a credit line to the material. If material is not included in the article's Creative Commons licence and your intended use is not permitted by statutory regulation or exceeds the permitted use, you will need to obtain permission directly from the copyright holder. To view a copy of this licence, visit http://creativecommons.org/licenses/by/4.0/. The Creative Commons Public Domain Dedication waiver (http://creativeco mmons.org/publicdomain/zero/1.0/) applies to the data made available in this article, unless otherwise stated in a credit line to the data. 
evidence suggesting impaired nitric oxide generation and endothelial dysfunction as a possible effect of PPIs [12-14]. This case report describes the abrupt onset of profound ED in a healthy young man after initiating over-the-counter omeprazole therapy, with erectile function rapidly normalizing following discontinuation of the drug.

\section{Case presentation}

A 38-year-old Caucasian man with a history of mild hypertension and who was otherwise healthy [never smoker, body mass index (BMI) $19.6 \mathrm{~kg} / \mathrm{m}^{2}$ ] began taking over-the-counter omeprazole $20 \mathrm{mg}$ daily owing to newonset gastroesophageal reflux symptoms. One day after initiating therapy (day 2 of therapy), the patient began to notice difficulty obtaining and maintaining an erection despite sustained libido. By day 3 of therapy, the patient was completely unable to obtain an erection. After the fourth day of therapy, the patient suspected the new medication as the culprit and discontinued use. Erectile function then returned to normal over the next several days. The patient had no history of previous ED and in the 2 years following the episode has had no further erectile difficulties. His only other medication was lisinopril $10 \mathrm{mg}$ daily, for which he had been on a stable dose for 11 years. No other medications or supplements were being used.

\section{Discussion and conclusions}

Several factors of this patient's clinical history create a compelling argument implicating omeprazole as a potent precipitant of ED. These include the temporal relationship of the onset of ED with the initiation of omeprazole therapy, the prompt resolution of symptoms following discontinuation of the drug, the absence of other readily apparent precipitating factors, and the absence of recurrent ED in the 2 years following the episode. Limitations include the possibility of an unrecognized factor that temporally coincided with omeprazole therapy and the potential of bias (for example, anchoring) affecting the accuracy of the history. However, thorough historytaking in this case likely minimizes the impact of these limitations.

The mention of ED as a potential adverse effect of PPI use is sparse within the medical literature. Likely the best documentation of this association is a pharmacovigilance report from the Netherlands that identified 17 cases of ED between 1992 and 2015 that were suspected to be related to omeprazole use [15]. Of the 17 cases, 3 were in men age $<40$ years with no known risk factors for ED. Two of those three men were taking omeprazole $40 \mathrm{mg}$ daily, and one was taking $20 \mathrm{mg}$ daily. Two of the men recovered following withdrawal of the drug, and the third man remained on the drug (with unresolved symptoms) until the end of followup. An earlier drug monitoring study from Sweden reported 15 cases of ED suspected to be related to omeprazole, with 2 of those cases in men age $<40$ years [16].

Several mechanisms of ED related to PPI use are possible. Induction of CYP3A4 may decrease levels of testosterone in some patients; however, such a mechanism would seem unlikely to cause profound ED after 2 days of therapy. Altered function of calcium channels within the corpus cavernosum may also be suggested [17]. The most likely mechanism would seem to be endothelial vasodilatory dysfunction mediated by impaired generation of nitric oxide. Evidence suggests that PPIs inhibit the enzyme dimethylarginine dimethylaminohydrolase (DDAH), which leads to blocked degradation of asymmetrical dimethylarginine (ADMA) and consequent impaired endothelial nitric oxide generation (increased ADMA levels are considered a potential marker of endothelial dysfunction) [18]. This mechanism could have especially potent effects on erectile function in patients with genetic polymorphisms leading to reduced baseline activity of DDAH, possibly explaining the abrupt onset and profound symptoms in this patient. Such endothelial dysfunction could also largely explain the associations of PPIs with chronic kidney disease and cardiovascular events (as well as a possible association with dementia) by accounting for chronic low levels of tissue ischemia with prolonged PPI use [5, $6,19]$.

In conclusion, the incidence of ED attributable to PPI use may be underrecognized. Further study is needed to better characterize the incidence of ED associated with PPI use, and whether this adverse effect is related to a mechanism of endothelial dysfunction. In the meantime, PPIs should be considered as a potential cause of ED in young and healthy patients. PPIs should also be considered as a cause or contributor to ED in older patients in whom ED is often attributed to age or comorbidities.

\section{Abbreviations}

ADMA: Asymmetrical dimethylarginine; DDAH: Dimethylarginine dimethylaminohydrolase; ED: Erectile dysfunction; PPI: Proton pump inhibitor.

\section{Acknowledgements \\ None.}

Authors' contributions

TWP is the sole author. Email address: twperry95@gmail.com. The author read and approved the final manuscript.

Funding

No funding was provided for this case report.

Availability of date and materials 
Not available.

\section{Declarations}

\section{Ethics approval and consent to participate} Not available.

\section{Consent for publication}

Written informed consent was obtained from the patient for publication of this case report and any accompanying images. A copy of the written consent is available for review by the Editor-in-Chief of this journal.

\section{Competing interests}

The author declares that he has no financial or nonfinancial competing interests.

Received: 27 March 2021 Accepted: 23 June 2021

Published online: 24 July 2021

\section{References}

1. Shin JM, Cho YM, Sachs G. Chemistry of covalent inhibition of the gastric $(\mathrm{H}+, \mathrm{K}+)$-ATPase by proton pump inhibitors. J Am Chem Soc. 2004;126(25):7800.

2. Laine L, Ahnen D, McClain C, Solcia E, Welsh JH. Review article: potential gastrointestinal effects of long-term acid suppression with proton pump inhibitors. Aliment Pharmacol Ther. 2000;14(6):651.

3. Cao F, Chen CX, Wang M, et al. Updated meta-analysis of controlled observational studies: proton-pump inhibitors and risk of Clostridium difficile infection. J Hosp Infect. 2018;98(1):4.

4. Khalili H, Huang ES, Jacobson BC, Carmago CA, Feskanich D, Chan AT. Use of proton pump inhibitors and risk of hip fracture in relation to dietary and lifestyle factors: a prospective cohort study. BMJ. 2012;344:372.

5. Lazarus $B, C$ Chen $Y$, Wilson FP, et al. Proton pump inhibitor use and the risk of chronic kidney disease. JAMA Intern Med. 2016;176(2):238.

6. Shiraev TP, Bullen A. Proton pump inhibitors and cardiovascular events: a systematic review. Heart Lung Circ. 2018;27(4):443-50.

7. Selvin E, Burnett AL, Platz EA. Prevalence and risk factors for erectile dysfunction in the US. Am J Med. 2007;120(2):151.
8. Fung MM, Bettencourt R, Barrett-Connor E. Heart disease risk factors predict erectile dysfunction 25 years later: the Rancho Bernardo Study. J Am Coll Cardiol. 2004;43(8):1405.

9. Grover SA, Lowensteyn I, Kaouache M, et al. The prevalence of erectile dysfunction in the primary care setting: importance of risk factors for diabetes and vascular disease. Arch Intern Med. 2006;166(2):213.

10. Wein AJ, Van Arsdalen KN. Drug-induced male sexual dysfunction. Urol Clin North Am. 1988;15(1):23.

11. Grimm RH Jr, Grandits GA, Prineas RJ, et al. Long-term effects on sexual function of five antihypertensive drugs and nutritional hygienic treatment in hypertensive men and women. Treatment of Mild Hypertension Study (TOMHS). Hypertension. 1997;29(1 pt 1):8.

12. Nolde $M$, Bahls $M$, Friedrich $N$, et al. Association of proton pump inhibitor use and metabolites of the nitric oxide pathway: a cross-sectional study. Pharmacotherapy. 2021;41(2):198-204.

13. Pinheiro LC, Oliveira-Paula GH, Portella RL, Guimaraes DA, de Angelis CD, Tanus-Santos JE. Omeprazole impairs vascular redox biology and causes xanthine oxidoreductase-mediated endothelial dysfunction. Redox Biol. 2016;9:134-43.

14. Yepuri G, Sukhovershin R, Nazari-Shafti TZ, Petrascheck M, Ghebre YT, Cooke JP. Proton pump inhibitors accelerate endothelial senescence. Circ Res. 2016;118:e36-42

15. Omeprazole and erectile dysfunction — an update. Bijiwerkingen Centrum Lareb.

16. Lindquist M, Edwards IR. Endocrine effects of omeprazole. BMJ. 1992;305(6851):451-2.

17. Sarioglu Y, Yildirim S, Utkan T, Yildirim MK, Uma S. Evidence of relaxant effect of omeprazole in rabbit corpus cavernosum in vitro. Life Sci. 2000;66(15):1411-21.

18. Dayoub H, Achan V, Adimoolam S, et al. Dimethylarginine dimethylaminohydrolase regulates nitric oxide synthesis. Circulation. 2003;108:3042-7.

19. Batchelor R, Gilmartin JF, Kemp W, Hopper I, Liew D. Dementia, cognitive impairment and proton pump inhibitor therapy: a systematic review. J Gastroenterol Hepatol. 2017;32(8):1426.

\section{Publisher's Note}

Springer Nature remains neutral with regard to jurisdictional claims in published maps and institutional affiliations.
Ready to submit your research? Choose BMC and benefit from:

- fast, convenient online submission

- thorough peer review by experienced researchers in your field

- rapid publication on acceptance

- support for research data, including large and complex data types

- gold Open Access which fosters wider collaboration and increased citations

- maximum visibility for your research: over $100 \mathrm{M}$ website views per year

At BMC, research is always in progress.

Learn more biomedcentral.com/submissions 